\title{
Efficacy of Cyanoacrylate and Black Braided Silk for The Closure of Incision After Surgical Removal of Impacted Third Molars: A Systematic Review
}

\author{
Divya James* and Uma Maheswari G. \\ Department of Oral and Maxillofacial Surgery, Saveetha Dental College and Hospital, Chennai, India
}

\begin{abstract}
Introduction: Wound closure is a part of any surgical procedure and the objective of laceration repair or incision closure is to approximate the edges of a wound so that natural healing process takes place. Over the years new biomaterials have been used as an alternate to conventional suture materials. Cyanoacrylate bio adhesives are one among them. They carry the advantage of rapid application, patient comfort, resistance to infection, hemostatic properties, and no suture removal anxiety. Hence this study was undertaken to study the effect of long chain cyanoacrylate as an adhesive for intraoral wound closure and also to explore its hemostatic and antibacterial effects. The aim of this study is to compare the efficacy of cyanoacrylate and black braided silk for the closure of surgical incision after removal of impacted third molars.
\end{abstract}

Search Strategy: Databases searched: PubMed CENTRAL, Google Scholar, Cochrane, Bibliographies of Clinical Studies and Reviews. Hand search done from 1988 till October 2016.

Selection Criteria: Clinical trials evaluating the severity of pain and hemostasis in the closure of incisions after surgically removed third molars.

Results: The reviews found some clinical evidence that, there is significant difference between sutures and cyanoacrylate on postoperative pain following mandibular third molar surgery. There is also significant difference between sutures and cyanoacrylate on haemostasis following mandibular third molar surgery.

Conclusion: The clinical evidence in this review is adequate to state that, there is a difference in postoperative pain and haemostasis following mandibular third molar surgery between black braided silk and cyanoacrylate.

Keywords: Cyanoacrylate, Black Braided Silk, Impacted Third Molars, Pain, Haemostasis

\section{Introduction}

The removal of mandibular third molar is a common procedure in a dental clinic. After removal of an impacted third molar the conventional method of suturing the surgical wound is by using black braided silk and leaving the wound to heal by primary intention. Suturing in the most posterior area of the oral cavity is not easy, it takes time and good suturing skills. Besides the difficulty faced during operative procedure, the patient has to come for a second visit after seven days for suture removal. Moreover, incompatibility with the tissues may cause foreign body reactions and fistula formation. Over - tight sutures may lead to necrosis and ischemia. Black braided silk has an effect known as 'wicking' which makes the operated site to retain bacteria which is followed by secondary infection, because the knots become a favorable place for bacterial colonies. To overcome these difficulties more effective method of surgical wound closure has been found with better efficiency and fewer complications.
Tissue adhesives as adopted the idea of suture less wound closure. Plastic adhesives were discovered in 1949 and 10 years later COOVER et al. reported their use in surgical procedures. Cyanoacrylate glue is the general term used for quick super bonding glues used as two separate liquids, one for pouring into the mould and other used as a hardener.

Aim

Aim of this systematic review is to compare the efficacy of cyanoacrylate and black braided silk for the closure of incision after surgical removal of impacted third molars.

\section{Structured Question}

Does cyanoacrylate has better efficacy than black braided silk in the closure of incision after surgical removal of impacted third molars?

\section{Pico Analysis}

Populations: Patients who are undergoing third molar surgery 
Intervention: Cyanoacrylate

Comparison: Black braided silk

Outcome: Severity of pain and hemostasis

Null Hypothesis: There is no difference in cyanoacrylate and black braided silk.

Alternative Hypothesis: There is difference in cyanoacrylate and black braided silk.

\section{Materials and Methods}

Sources used for identification of studies included or considered for this review, detailed search strategies were carried out on the following databases.

- PubMed

- PubMed Advanced search

- MEDLINE

Language: There was no language restriction during the electronic search.

Hand Searching: The following journals were hand searched: International Journal of Oral and Maxillofacial Surgery, British Journal of Oral and Maxillofacial Surgery, Journal of Oral and Maxillofacial Surgery, Oral Surg Oral Med Oral Pathol Oral Radiol Endod

Inclusion Criteria: Criteria for considering studies for this review.

Types of Studies: Randomized controlled trial or clinical trials evaluating and comparing the effectiveness of cyanoacrylate and black braided silk for the closure of incision after surgical removal of impacted third molars.

Types of Participants: All participants undergoing third molar surgery.

\section{Type of Intervention}

Cyanoacrylate

\section{Types of Outcome Measures}

To evaluate severity of pain and hemostasis of cyanoacrylate and black braided silk for the closure of incision after surgical removal of impacted third molars.

\section{Exclusion Criteria}

- The following studies were excluded,

- Case reports / case series

- Animal studies

- In vitro studies

- Studies involving primary teeth

- Systematic reviews

Annals of Applied Bio-Sciences, Vol. 4; Issue 4: 2017

\section{Results}

Description Of Studies: The search identified 1 article. Full articles were obtained. 3 hand searched article fulfilled the inclusion criteria. Therefore, a total of 4 articles fulfilled all criteria for inclusion.

\section{Quality Assessment}

The quality assessment of included trials was undertaken independently as a part of data extraction process. Four main quality criteria were examined.

1. Method of Randomization, recorded as

a) Yes - adequate as described in the text

b) No - inadequate as described in the text

c) Unclear in the text

2. Allocation Concealment, recorded as

a) Yes - adequate as described in the text

b) No - inadequate as described in the text

c) Unclear in the text

3. Outcome assessor blinded to intervention, recorded as

a) Yes - adequate as described in the text

b) No - inadequate as described in the text

c) Unclear in the text

4. Completeness of follow-up (was there a clear explanation for withdrawals and dropouts in each treatment group) assessed as :

a) Yes - dropouts were explained

b) No-dropouts were not explained

c) None - no dropouts or withdrawals

Other methodological criteria examined included:

1. Presence or absence of sample size calculation

2. Comparability of groups at the start

3. Clear inclusion / exclusion criteria

4. Presence/absence of estimate of measurement error. The validity and reproducibility of the method of assessment.

Risk of Bias In Included Studies: The assessments for the four main methodological quality items are shown in table. The study was assessed by to have a "high risk" of bias if it did not record a "yes" in 3 or more of the 4 main categories , "moderate" if 2 out of 4 categories did not record a "yes" and "low" if randomization, assessor blinding and completeness of follow up were considered adequate.

\section{Discussion}

Interpretation of Results: According to Sneha Sethiya et al. ${ }^{1}$, the severity of pain was significantly $(\mathrm{p}<0.05)$ less in 
TABLE 1: VARIABLES OF INTEREST

\begin{tabular}{|c|c|c|c|c|c|c|c|c|c|}
\hline \multicolumn{5}{|c|}{ Sr. No. } & \multicolumn{5}{|c|}{ Variables of interest } \\
\hline \multicolumn{5}{|l|}{1.} & \multicolumn{5}{|c|}{ Severity of pain } \\
\hline \multicolumn{5}{|l|}{2.} & \multicolumn{5}{|c|}{ Hemostasis } \\
\hline $\begin{array}{l}\text { Sr. } \\
\text { No. }\end{array}$ & Author & Year & Country & Study design & $\begin{array}{l}\text { Sample } \\
\text { size }\end{array}$ & Age & Set - up & $\begin{array}{l}\text { Technique } \\
\text { used }\end{array}$ & $\begin{array}{l}\text { Method of } \\
\text { evaluation }\end{array}$ \\
\hline 1. & $\begin{array}{l}\text { Sneha Setiya, } \\
\text { Rajshekhar Halli, } \\
\text { Anand Shah, } \\
\text { Gaurav Chabbaria, } \\
\text { Tarun Singh }\end{array}$ & 2014 & India & $\begin{array}{l}\text { Prospective } \\
\text { controlled } \\
\text { clinical study }\end{array}$ & 50 & $\begin{array}{l}18-35 \\
\text { years }\end{array}$ & University & $\begin{array}{l}\text { Silk sutures } \\
\text { and } \\
\text { cyanoacrylate }\end{array}$ & $\begin{array}{l}\text { Pain and bleeding } \\
\text { were measured } \\
\text { using visual } \\
\text { analogue scale. }\end{array}$ \\
\hline 2. & $\begin{array}{l}\text { Mehdi Ghoreishian, } \\
\text { Rasoul Gheisari, } \\
\text { Maasoumeh Fayazi }\end{array}$ & 2009 & Iran & $\begin{array}{l}\text { Controlled } \\
\text { clinical trial }\end{array}$ & 16 & $\begin{array}{l}19-24 \\
\text { years }\end{array}$ & University & $\begin{array}{l}\text { Silk sutures } \\
\text { and } \\
\text { cyanoacrylate }\end{array}$ & $\begin{array}{l}\text { Pain and bleeding } \\
\text { were measured } \\
\text { using visual } \\
\text { analogue scale. }\end{array}$ \\
\hline 3. & $\begin{array}{l}\text { M. Gogulanathan, } \\
\text { P. Elavenil, A. } \\
\text { Gnanam, V. B. } \\
\text { Krishnakumar Raja }\end{array}$ & 2015 & India & $\begin{array}{l}\text { Prospective, } \\
\text { randomized } \\
\text { controlled } \\
\text { clinical trial }\end{array}$ & 30 & - & College & $\begin{array}{l}\text { Silk sutures } \\
\text { and } \\
\text { cyanoacrylate }\end{array}$ & $\begin{array}{l}\text { Pain and bleeding } \\
\text { were measured } \\
\text { using numerical } \\
\text { rating scale. }\end{array}$ \\
\hline 4. & $\begin{array}{l}\text { Ajit D. Joshi, } \\
\text { Harish Saluja, } \\
\text { Uma Mahindra, } \\
\text { Rajshekhar Halli }\end{array}$ & 2011 & India & $\begin{array}{l}\text { Randomized } \\
\text { controlled } \\
\text { clinical trial }\end{array}$ & 30 & $\begin{array}{l}20-32 \\
\text { years }\end{array}$ & University & $\begin{array}{l}\text { Silk sutures } \\
\text { and } \\
\text { cyanoacrylate }\end{array}$ & $\begin{array}{l}\text { Pain and bleeding } \\
\text { were measured } \\
\text { using visual } \\
\text { analogue scale. }\end{array}$ \\
\hline
\end{tabular}

Table 3: RESULTS

\begin{tabular}{|c|c|c|c|c|c|}
\hline $\begin{array}{l}\text { Sr. } \\
\text { No. }\end{array}$ & $\begin{array}{l}\text { Author and } \\
\text { Year }\end{array}$ & Materials used & $\begin{array}{l}\text { Method of } \\
\text { evaluation }\end{array}$ & Mean Values & Outcomes \\
\hline 1. & $\begin{array}{l}\text { Sneha Setiya, } \\
2014\end{array}$ & $\begin{array}{l}\text { Silk sutures } \\
\text { and } \\
\text { cyanoacrylate }\end{array}$ & $\begin{array}{l}\text { Pain and } \\
\text { bleeding were } \\
\text { measured } \\
\text { using visual } \\
\text { analogue scale. }\end{array}$ & $\begin{array}{l}\text { Pain } \\
\text { Group } 1 \text { (Sutures) } \\
\text { Day } 1-2.42 \\
\text { Day } 2-1.98 \\
\text { Day } 7-0.26 \\
\text { Group } 2 \text { (Cyanoacrylate) } \\
\text { Day } 1-2.02 \\
\text { Day } 2-1.2 \\
\text { Day } 7-0 \\
\text { Hemostasis } \\
\text { Group } 1 \text { (Sutures) } \\
\text { Day } 1-1 \\
\text { Day } 2-0 \\
\text { Day } 7-0 \\
\text { Group } 2 \text { (Cyanoacrylate) } \\
\text { Day } 1-0.2 \\
\text { Day } 2-0 \\
\text { Day } 7-0\end{array}$ & $\begin{array}{l}\text { Day } 1 \text { - There was significant } \\
\text { difference in pain and hemostasis } \\
\text { between the two groups } \\
\text { Day } 2 \text { - There was significant } \\
\text { difference in pain but there was no } \\
\text { significant difference in hemostasis } \\
\text { between the two groups. } \\
\text { Day } 7 \text { - There was significant } \\
\text { difference in pain but there was no } \\
\text { significant difference in hemostasis } \\
\text { between the two groups. }\end{array}$ \\
\hline 2. & $\begin{array}{l}\text { Mehdi } \\
\text { Ghoreishian, } \\
2009\end{array}$ & $\begin{array}{l}\text { Silk sutures } \\
\text { and } \\
\text { cyanoacrylate }\end{array}$ & $\begin{array}{l}\text { Pain and } \\
\text { bleeding were } \\
\text { measured } \\
\text { using visual } \\
\text { analogue scale. }\end{array}$ & $\begin{array}{l}\text { Pain } \\
\text { Group } 1 \text { (Sutures) } \\
\text { Day } 1-4.38 \\
\text { Day } 2-3.63 \\
\text { Day } 3-2.47 \\
\text { Day } 4-0.71 \\
\text { Day } 5-0.59\end{array}$ & $\begin{array}{l}\text { Day } 1 \text { - There was significant } \\
\text { difference in pain and hemostasis } \\
\text { between the two groups. } \\
\text { Day } 2 \text { - There was significant } \\
\text { difference in pain and hemostasis } \\
\text { between the two groups. }\end{array}$ \\
\hline
\end{tabular}

Table Cont. 
Cont. Table

\begin{tabular}{|c|c|c|c|c|c|}
\hline $\begin{array}{l}\text { Sr. } \\
\text { No. }\end{array}$ & $\begin{array}{l}\text { Author and } \\
\text { Year }\end{array}$ & Materials used & $\begin{array}{l}\text { Method of } \\
\text { evaluation }\end{array}$ & Mean Values & Outcomes \\
\hline & & & & $\begin{array}{l}\text { Group } 2 \text { (Cyanoacrylate) } \\
\text { Day } 1-4.19 \\
\text { Day } 2-3.09 \\
\text { Day } 3-2.47 \\
\text { Day } 4-1.34 \\
\text { Day } 5-1.31 \\
\text { Hemostasis } \\
\text { Group } 1 \text { (Sutures) } \\
\text { Day } 1-3 \\
\text { Day } 2-1.50 \\
\text { Day } 3-0 \\
\text { Group } 2 \text { (Cyanoacrylate) } \\
\text { Day } 1-2 \\
\text { Day } 2-1 \\
\text { Day } 3-0\end{array}$ & $\begin{array}{l}\text { Day } 3 \text { - There was no significant } \\
\text { difference in pain and hemostasis } \\
\text { between the two groups. } \\
\text { Day } 4 \text { - There was significant } \\
\text { difference in pain between the two } \\
\text { groups. } \\
\text { Day } 5 \text { - There was significant } \\
\text { difference in pain between the two } \\
\text { groups. }\end{array}$ \\
\hline 3. & $\begin{array}{l}\text { M. } \\
\text { Gogulanathan, } \\
2015\end{array}$ & $\begin{array}{l}\text { Silk sutures } \\
\text { and } \\
\text { cyanoacrylate }\end{array}$ & $\begin{array}{l}\text { Pain and } \\
\text { bleeding were } \\
\text { measured } \\
\text { using numerical } \\
\text { rating scale. }\end{array}$ & $\begin{array}{l}\text { Pain } \\
\text { Group } 1 \text { (Sutures) } \\
3.5 \pm 1.6 \\
\text { Group } 2 \text { (Cyanoacrylate) } \\
2.0 \pm 1.5 \\
\text { Hemostasis } \\
\text { Group } 1 \text { (Sutures) } \\
251.9 \pm 67.9 \\
\text { Group } 2 \text { (Cyanoacrylate) } \\
1.2 \pm 0.4\end{array}$ & $\begin{array}{l}\text { There was significant difference in } \\
\text { pain and hemostasis between the } \\
\text { two groups. }\end{array}$ \\
\hline 4. & $\begin{array}{l}\text { Ajit D. Joshi, } \\
2011\end{array}$ & $\begin{array}{l}\text { Silk sutures } \\
\text { and } \\
\text { cyanoacrylate }\end{array}$ & $\begin{array}{l}\text { Pain and } \\
\text { bleeding were } \\
\text { measured } \\
\text { using visual } \\
\text { analogue scale. }\end{array}$ & $\begin{array}{l}\text { Pain } \\
\text { Group } 1 \text { (Sutures) } \\
\text { Day } 1-1.43 \\
\text { Day } 2-1.37 \\
\text { Day } 3-1.32 \\
\text { Day } 4-1.2 \\
\text { Day } 5-1.2 \\
\text { Group } 2 \text { (Cyanoacrylate) } \\
\text { Day } 1-1.3 \\
\text { Day } 2-1.2 \\
\text { Day } 3-1.3 \\
\text { Day } 4-1.2 \\
\text { Day } 5-1.2 \\
\text { Hemostasis } \\
\text { Group } 1 \text { (Sutures) } \\
\text { Day } 1-0.17 \\
\text { Day } 2-0 \\
\text { Day } 3-0 \\
\text { Group } 2 \text { (Cyanoacrylate) } \\
\text { Day } 1-0 \\
\text { Day } 2-0 \\
\text { Day } 3-0\end{array}$ & $\begin{array}{l}\text { Day } 1 \text { - There was significant } \\
\text { difference in pain and hemostasis } \\
\text { between the two groups. } \\
\text { Day } 2 \text { - There was significant } \\
\text { difference in pain but there was no } \\
\text { significant difference in hemostasis } \\
\text { between the two groups. } \\
\text { Day } 3 \text { - There was significant } \\
\text { difference in pain but there was no } \\
\text { significant difference in hemostasis } \\
\text { between the two groups. } \\
\text { Day } 4 \text { - There was no significant } \\
\text { difference in pain between the two } \\
\text { groups. } \\
\text { Day } 5 \text { - There was no significant } \\
\text { difference in pain between the two } \\
\text { groups. }\end{array}$ \\
\hline
\end{tabular}

Table 5: Summation table for individual parameters

\begin{tabular}{|c|l|c|l|l|}
\hline Sr. No. & Author & Year & Evaluation period & Outcome \\
\hline 1. & Sneha Setiya et al. & 2014 & $1^{\text {st }}, 2^{\text {nd }}$ and $7^{\text {th }}$ day & $\begin{array}{l}\text { The severity of pain and the bleeding was less in study } \\
\text { group as compared to control group. }\end{array}$ \\
\hline 2. & Mehdi Ghoreishian et al. & 2009 & $\begin{array}{l}\text { Pain: } 1^{\text {st }} \text { to } 5^{\text {th }} \text { day } \\
\text { Hemostasis: } 1^{\text {st }} \text { to } \\
3^{\text {rd }} \text { day }\end{array}$ & $\begin{array}{l}\text { There was no significant difference in severity of pain in } \\
\text { study group and control group. There was less significant } \\
\text { difference in the bleeding in study group and control } \\
\text { group on the } 1^{\text {st }} \text { and } 2^{\text {nd }} \text { postoperative days. There was no } \\
\text { significant difference between the two methods on the third } \\
\text { day }\end{array}$ \\
\hline
\end{tabular}




\begin{tabular}{|c|l|l|l|l|} 
Sr. No. & Author & Year & Evaluation period & Outcome \\
\hline 3. & M. Gogulanathan et al. & 2015 & $\begin{array}{l}\text { Pain: } 1^{\text {st }} \text { and } 7^{\text {th }} \text { day } \\
\text { Hemostasis: Time } \\
\text { noted in seconds } \\
\text { for bleeding to stop } \\
\text { after closure. }\end{array}$ & $\begin{array}{l}\text { The postoperative pain was significantly lower in the control } \\
\text { group as compared to study group. The mean time taken } \\
\text { for hemostasis in study group is } 200 \text { times faster than the } \\
\text { control group. }\end{array}$ \\
\hline 4. & Ajit D. Joshi et al. & 2011 & $\begin{array}{l}\text { Pain: } 1^{\text {st }} \text { to } 5^{\text {th }} \text { day } \\
\text { Hemostasis: } 1^{\text {st }} \text { to } \\
3^{\text {rd }} \text { day }\end{array}$ & $\begin{array}{l}\text { There was significant difference in severity of pain in study } \\
\text { group and control group. The postoperative bleeding was } \\
\text { less significant in the control group as compared to study } \\
\text { group on the } 1^{\text {st }} \text { and } 2^{\text {nd }} \text { days. Patients were unable to } \\
\text { make any significant remarks over the bleeding on the } 3^{\text {rd }} \\
\text { postoperative day }\end{array}$ \\
\hline
\end{tabular}

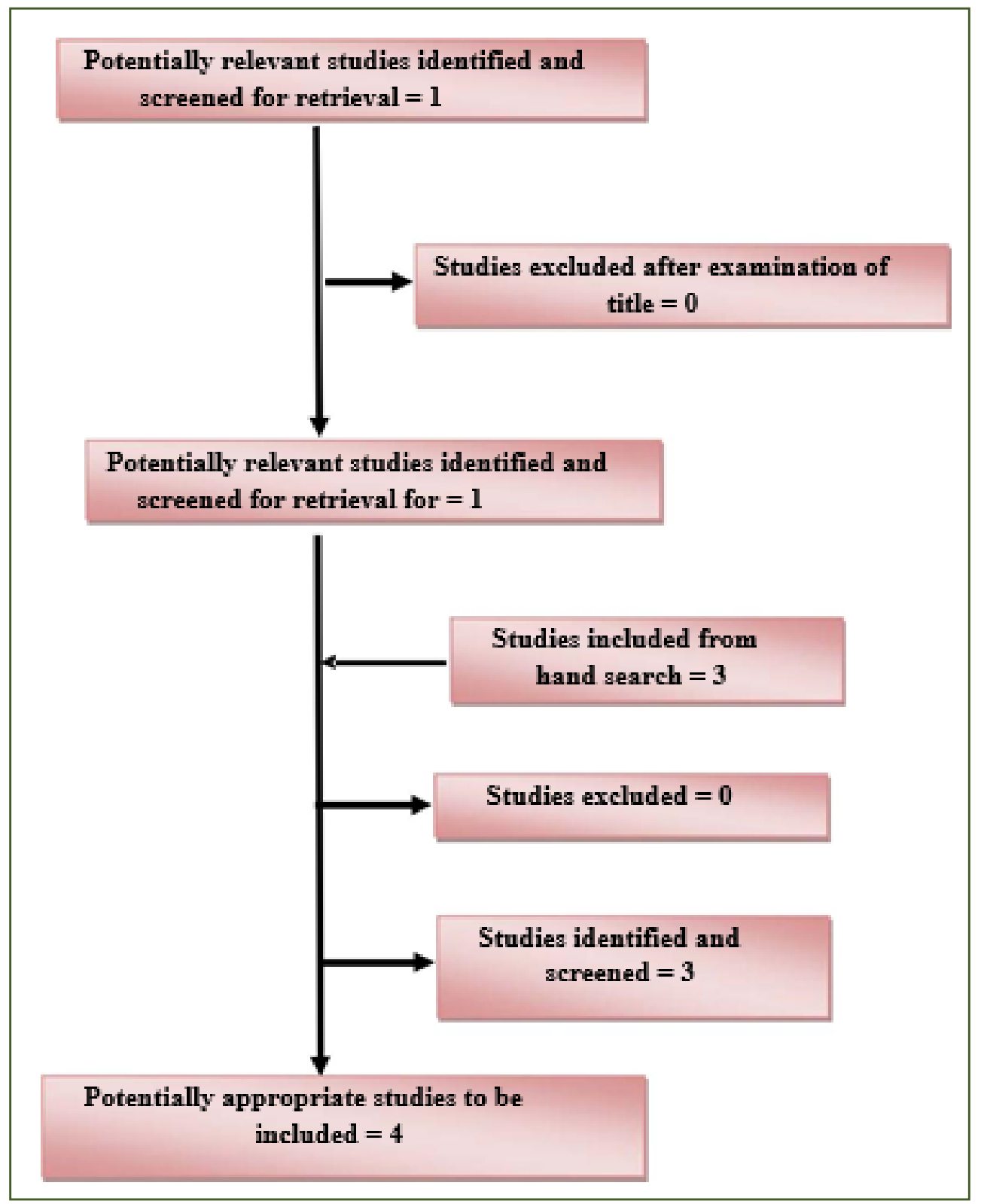

CHART 1: SEARCH FLOWCHART

http://www.pacificejournals.com/aabs 

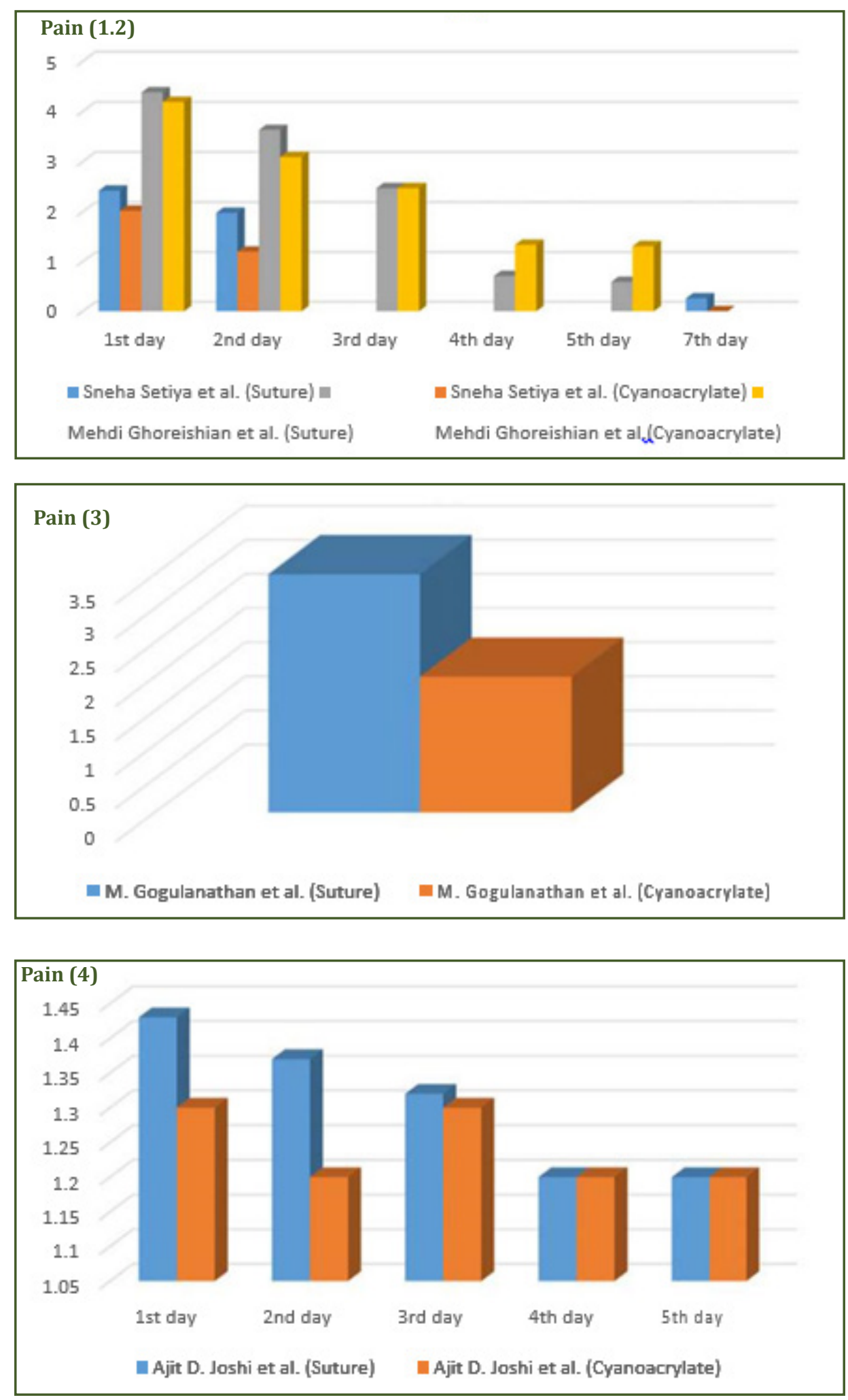

GRAPH 1: PRIMARY OUTCOME (PAIN). 

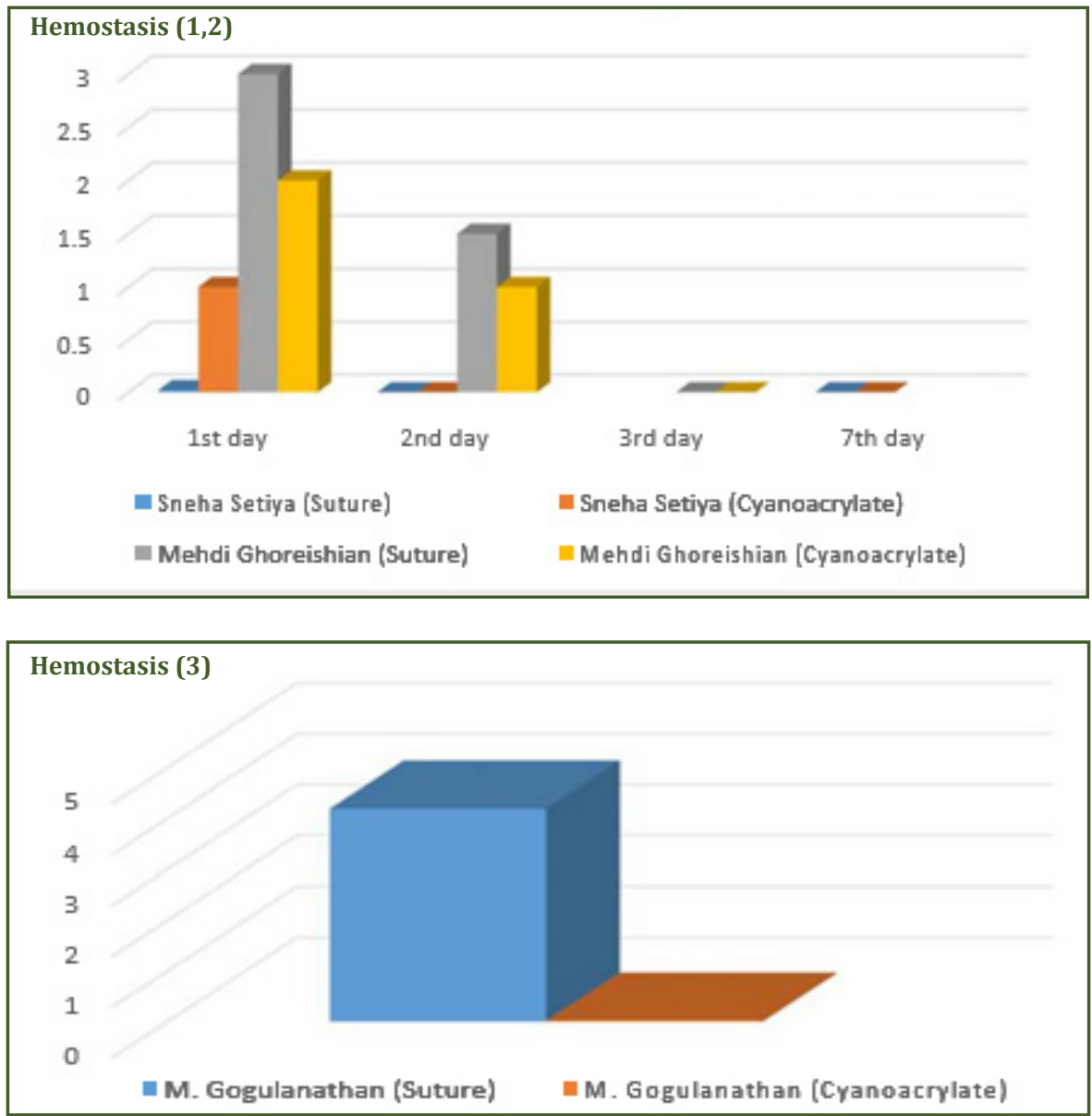

GRAPH 2: SECONDARY OUTCOME (HEMOSTASIS)

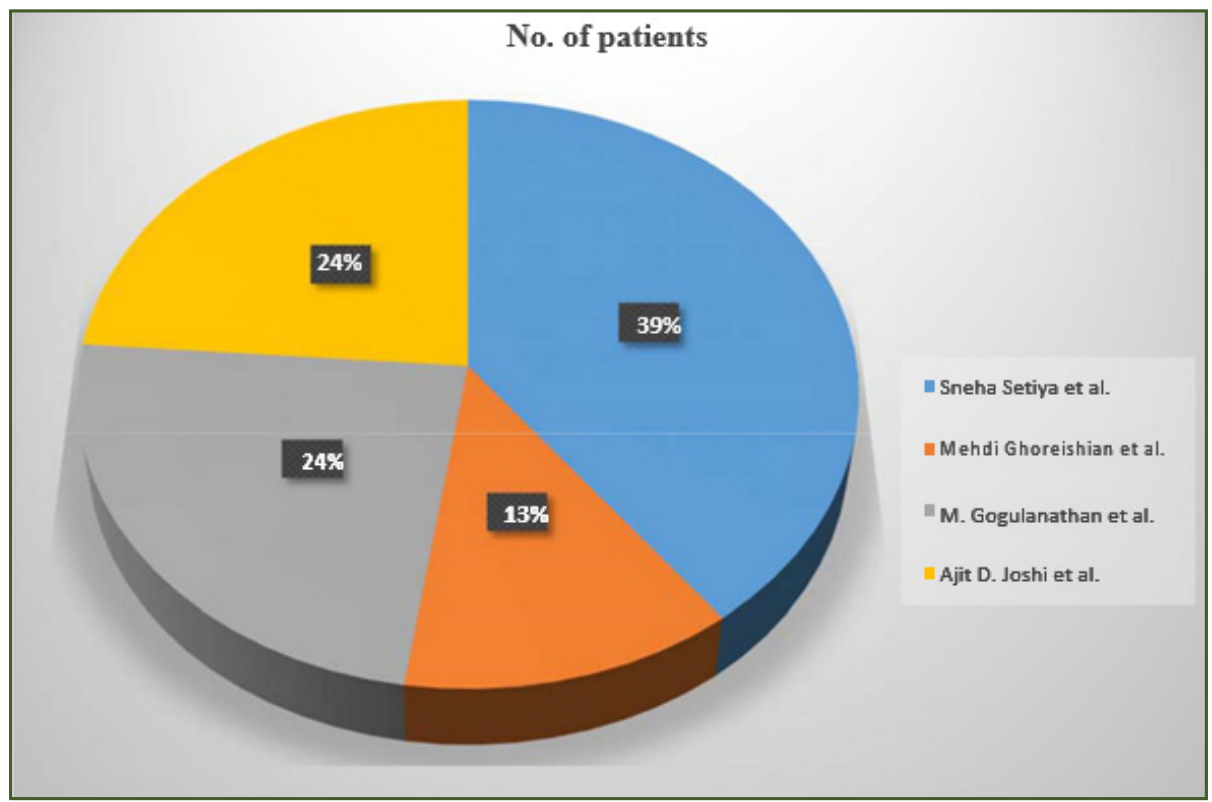

GRAPH 3: SAMPLE SIZE

http://www.pacificejournals.com/aabs 
the study group as compared to the control group on the1st, 2nd, and7th day postoperatively. Mann-Whitney U test was used to compare pain scores in both the groups. First cross-tabulation test was used to compare postoperative bleeding in both the groups and statistical analysis showed that there was significant difference in bleeding in the study group when comparison was done between the two groups on the1st postoperative day $(\mathrm{p}<0.05)$.

According to Mehdi Ghoreishian et al. ${ }^{2}$, there was no significant difference in the severity of pain between the 2 methods on the right and left sides of the mandible at all times recorded $(P>0.05)$. The data analysis showed that postoperative bleeding with the cyanoacrylate adhesive method was less significant than with suturing on the first and second days after surgery $(P<0.05)$; however, the bleeding index showed no significant difference $(P>0.05)$ between the 2 methods on the third day.

According to M. Gogulanathan et $\mathrm{al}^{3}$, compared to the control group, the study group showed a statistically significant reduction in the durations for achieving local haemostasis. The mean time for achieving haemostasis in the study group was 200 times faster than that in the control group (1.2 s vs. $251.9 \mathrm{~s})$. The postoperative pain score assessed on the first postoperative day was also significantly lower for the study group patients (2.0) as compared with the control group (3.5).

According to Ajit D. Joshi et al. ${ }^{4}$, there was significant difference in the severity of pain between the two methods on the right and left sides of the mandible at all times recorded $(\mathrm{P}<0.05)$. The analysis showed that the severity of pain in closure with suture was more in first 3 days and later on it became same but marked elevation in pain have been noted on the second day. The data analysis showed that postoperative bleeding with the cyanoacrylate adhesive method was less significant than with suturing on the first and second days after surgery $(\mathrm{P}<0.05)$; however, the bleeding index showed no significant difference $(\mathrm{P}<0.05)$ between the two methods on the third day. Patients were unable to make any significant remarks over the bleeding on 3rd postoperative day.

Defending The Result: All the four studies discussed, compare the closure of surgical incisions after surgical removal of impacted third molars with silk sutures and cyanoacrylate. The two parameters assessed were pain and hemostasis. In the first and third study, the severity of pain and the bleeding was less in cyanoacrylate group as compared to control group. In the second study, there was no significant difference in severity of pain in both the groups. There was less significant difference in the bleeding in study group and control group on the $1^{\text {st }}$ and $2^{\text {nd }}$ postoperative days. In the fourth study, there was significant difference in severity of pain in both the groups. The postoperative bleeding was less significant in the control group as compared to study group on the $1^{\text {st }}$ and $2^{\text {nd }}$ days.

Quality of Evidence: All studies included in the review were randomized controlled studies. All the four studies included in this review had a level of evidence 2. Risk of bias in one study showed a low risk of bias. Hence the interpretation obtained from these studies are reliable.

Inference: Use of cyanoacrylate adhesive had certain advantages over conventional suturing technique like it was hemostatic, reduced pain and avoids second visit for suture removal. The cost of tissue adhesive was the only limitation. Thus we can conclude that cyanoacrylate glue is a better alternative to conventional suturing for closure of intraoral minor surgical wound.

Surindar et al. ${ }^{5}$ studied the efficacy of cyanoacrylate in patients undergoing various minor intraoral procedures and found it to be a hemostatic adhesive that polymerizes almost immediately on contact with cut oral tissue. The same was noted by Kulkarni et al. ${ }^{6}$ after the use of cyanoacrylate in periodontal flap surgery. Immediate hemostasis in bleeding pulp took place in the study conducted by Milton et al. ${ }^{7}$ . Fauad and Maged ${ }^{8}$ described the hemostatic effect of cyanoacrylate glue on warfarin- treated patients undergoing oral surgery.

Implication for Practice: Cyanoacrylate is an effective means of mechanical as well as biological closure of intraoral wounds. This tissue adhesive markedly hastens haemostasis, reduces the operating time, and demonstrates less postoperative pain, thereby enhancing patient comfort significantly. Also it avoids second visit for suture removal

Implication of Research: All Studies carried out are randomized control trial. So the results were reliable and further research is not required.

\section{Summary}

Aim of this systematic review is to compare the efficacy of cyanoacrylate and black braided silk for the closure of incision after surgical removal of impacted third molars. Randomized controlled trial or clinical trials evaluating and comparing the effectiveness cyanoacrylate and black braided silk for the closure of incision after surgical removal of impacted third molars.

Trials were selected if they met the following criteria. Randomized controlled clinical trials comparing silk sutures and cyanoacrylate for surgical closure in patients 
undergoing lower third molar surgery. The studies for inclusion in this review represents comparison of silk sutures and cyanoacrylate in reducing postoperative pain and bleeding after third molar surgery.

The databases PUBMED CENTRAL and MEDLINE were searched for the related topic till November 2016. The search identified 1 publication. Hand search was done and 3 articles were obtained. Full articles were obtained for 4 studies.

Therefore, a total of 4 publications fulfilled all criteria for inclusion.

\section{Conclusion}

From this systematic review it can be concluded that, cyanoacrylate is a better alternative for intraoral minor surgical procedures as tissue glue, was found to be haemostatic in nature, was helpful in reduction of pain and patients need not visit again for suture removal. Even this procedure was comfortable for the surgeon.

\section{Acknowledgements}

Saveetha Dental College and Hospital, Chennai, India

\section{Reference}

1. Setiya, S., Halli, R., Shah, A., Chhabaria, G., \& Singh, T. (2015). Comparative evaluation of efficacy of tissue glue and sutures after surgical removal of impacted mandibular third molars - A prospective controlled clinical study. Journal of
Oral and Maxillofacial Surgery, Medicine, and Pathology, 27(2), 183-188.

2. Ghoreishian, M., Gheisari, R., \& Fayazi, M. (2009). Tissue adhesive and suturing for closure of the surgical wound after removal of impacted mandibular third molars: A comparative study. Oral surgery, oral medicine, oral pathology, oral radiology, and endodontics., 108(1).

3. Gogulanathan, M., Elavenil, P., Gnanam, A., \& Raja, V. (2015). Evaluation of fibrin sealant as a wound closure agent in mandibular third molar surgery--a prospective, randomized controlled clinical trial. International journal of oral and maxillofacial surgery., 44(7), 871-5.

4. Joshi, A. D., Saluja, H., Mahindra, U., \& Halli, R. (2011). A comparative study: Efficacy of tissue glue and sutures after impacted Mandibular Third molar removal. , 10(4).

5. Surindar NB, Joe F. Use of cyanoacrylate adhesives in dentistry. JADA 1968;77:831-7.

6. Kulkarni S, Dodwad V, Chava V. Healing of periodontal flaps when closed with silk sutures and N-butyl cyanoacrylate: a clinical and histological study. Indian J Dent Res 2007;18:72-7.

7. Milton DB, Fran AC, Marvin PL, Louis JB. Pulpal response to isobutyl cyanoacrylate in human teeth. JADA 1971;83:140-5.

8. Fauad AA, Maged ZA. Hemostatic effect of n-butyl2-cyanoacrylate (histoacryl) glue in warfarin treated patients undergoing oral surgery. JOral Maxillofac Surg 2003;61:1405-9.

*Corresponding author:

Dr. Divya James, Saveetha Girls Hostel, Saveetha Dental College and Hospital, 162, Poonamallee High Road, Vellapanchavadi, Chennai - 600077, India.

Email: divyajames3112@gmail.com 